\title{
DĄBROWSZCZACY: MIĘDZY SYMBOLEM ANTYFASZYZMU A POLITYKĄ ANTYKOMUNIZMU*
}

\section{WSTĘP}

W 1990 roku z Grobu Nieznanego Żołnierza zdemontowano tablice poświęcone miejscom walki „Wojska Polskiego z faszyzmem i hitleryzmem" umieszczone tam przez władze komunistyczne tuż po zakończeniu drugiej wojny światowej. Jedna $z$ nich upamiętniała walki toczone w trakcie wojny domowej w Hiszpanii przez polskich ochotników nazywanych „dąbrowszczakami”. Akt usuwania z centralnego miejsca pamięci narodowej symboli legitymizujących władze z poprzedniego ustroju był formą symbolicznego rozliczenia z przeszłością i częścią rytuału przejęcia władzy przez siły odwołujące się do innego kanonu pamięci.

Historię hiszpańskiej wojny domowej, jej weteranów oraz peerelowską legendę generała „Waltera” — Karola Świerczewskiego — ówczesne władze potraktowały jako część wrogiej nowej Polsce tradycji komunistycznej. Wkrótce ich historia została niemal całkiem zapomniana w polskim społe-

Adres do korespondencji: j.wysmułek@isppan.waw.pl; ORCID 0000-0002-7283-4130

* Tekst powstał w ramach grantu pt. „Dekomunizacja przestrzeni publicznej w Polsce. Rywalizacja o pamięć w wymiarze lokalnym”, realizowanego w Instytucie Studiów Politycznych Polskiej Akademii Nauk w roku 2018. Grant nr 4/VIIKMN/2018 finansowany był ze środków przyznanych przez Ministerstwo Nauki i Szkolnictwa Wyższego. 
czeństwie (Kwiatkowski 2008, s. 261-262). Jednakże blisko trzydzieści lat później, gdy prawicowy rząd Prawa i Sprawiedliwości rozpoczął usuwanie z przestrzeni publicznej wszelkich pozostałych po systemie komunistycznym symboli, w obronie ponownie "dekomunizowanych" dąbrowszczaków wystąpili przedstawiciele młodego pokolenia. W krótkim czasie nielicznym grupom lewicowych społeczników z kilku dużych polskich miast udało się nie tylko doprowadzić do wstrzymania usuwania nazw ulic Dąbrowszczaków w Warszawie i Olsztynie oraz przez pewien czas również w Gdańsku ${ }^{1}$, ale także podjąć szereg działań publicznych mających na celu popularyzację historii sprzed lat.

Dlaczego współcześnie - osiemdziesiąt lat po zakończeniu wojny domowej w Hiszpanii - dąbrowszczacy stali się ponownie aktualnym i godnym obrony symbolem $\mathrm{w}$ ocenie osób $\mathrm{z}$ pokolenia wychowanego już zazwyczaj w czasach III RP? Odpowiedź jest istotna w wymiarze politycznym z kilku powodów. Po pierwsze, od początku lat dziewięćdziesiątych XX wieku pamięć zbiorowa Polaków była kształtowana głównie przez środowiska i instytucje realizujące prawicową, antykomunistyczną narrację historyczną, przedstawiciele środowisk lewicowych i liberalnych natomiast $\mathrm{w}$ niewielkim stopniu angażowali się $\mathrm{w}$ budowanie odrębnej wizji polityki historycznej. Zmiana ta świadczy więc o pojawieniu się $\mathrm{W}$ przestrzeni pamięci społecznej nowego, aktywnego podmiotu „aktora pamięci” lewicowej. Po drugie, chociaż powszechnie uważa się zmianę pokoleniową za istotny czynnik zmiany społecznej, wciąż mało jest $\mathrm{w}$ Polsce badań podejmujących to zagadnienie $\mathrm{z}$ perspektywy pamięci społecznej (Schuman, Belli, Bischoping 1997). Po trzecie, zmiana ta jest istotna również $\mathrm{w}$ wymiarze analizy mechaniki rywalizacji $\mathrm{w}$ polu pamięci, ponieważ jest cennym przykładem tego, jak skuteczny może być wpływ oddolnych działań $\mathrm{w}$ zakresie lokalnej pamięci i tożsamości.

W związku z tym poszukiwałem odpowiedzi na następujące pytania:

Jakie czynniki wpłynęły na to, że pamięć o dąbrowszczakach ponownie stała się punktem sporu we współczesnej Polsce?

Jak ocenia się historyczną rolę dąbrowszczaków i jakie nadaje się jej obecnie znaczenia?

\footnotetext{
${ }^{1} \mathrm{~W}$ tych trzech miastach władze samorządowe zdecydowały się zaskarżyć „dekomunizacyjne” decyzje wojewodów. Naczelny Sąd Administracyjny uchylił te decyzje w Olsztynie i Warszawie, w Gdańsku pozostawił w mocy. W Swarzędzu wojewoda wielkopolski dokonał zmiany nazwy Osiedla Dąbrowszczaków. Decyzja ta również została zaskarżona przez władze miasta, a Wojewódzki Sąd Administracyjny ją uchylił.
} 
Kto stoi za obroną i promocją historii dąbrowszczaków w Polsce?

Rozważania takie mieszczą się w polach polityki pamięci, antropologii polityki oraz socjologii ruchów społecznych. Ramę teoretyczną stanowią trzy pojęcia: pamięć, tożsamość i polityka. „[...] kontekst polityczny jak stwierdza Artur Lipiński (2014, s. 34) — pozwala na określenie zależności między treścią i sposobami upamiętniania reprezentacji przeszłości [...] a konkretną konfiguracją aktorów politycznych i ich interesami, rolą instytucji politycznych, politykami szczegółowymi realizowanymi przez instytucje państwa, typem systemu politycznego i jego historią, walką polityczną, podziałami politycznymi w społeczeństwie czy relacjami na arenie międzynarodowej".

\section{METODOLOGIA BADANIA}

Badanie, na którym się tu opieram, jest częścią większego projektu badawczego poświęconego problemowi dekomunizacji przestrzeni publicznej w Polsce na mocy ustawy z 1 kwietnia 2016 r. Na jego potrzeby między marcem 2018 a marcem 2019 roku zostało zrealizowanych 67 wywiadów indywidualnych oraz 3 nagrania $z$ wydarzeń publicznych, w których brały udział osoby zaangażowane $\mathrm{w}$ proces dekomunizacji. Respondentów wybierano za pomocą dwóch metod: na podstawie kwerendy prasowej oraz metodą tzw. kuli śniegowej, to jest uzyskując nowe kontakty od osób, z którymi przeprowadzono już wywiad. Należeli oni do czterech głównych kategorii: (1) społeczników; (2) samorządowców; (3) byłych i obecnych pracowników Instytutu Pamięci Narodowej; (4) ekspertów w zakresie kultury i polityki pamięci. Niektórych można było zaliczyć do kilku kategorii. Większość wywiadów trwała około godziny. Pytanie otwierające dotyczyło opinii respondenta na temat sensu i celu przeprowadzania dekomunizacji przestrzeni publicznej we współczesnej Polsce. W dalszej części wywiadu respondenci byli proszeni o opis podejmowanych przez siebie działań społecznych oraz stojących za nimi motywacji, inspiracji i uwarunkowań. Byli również pytani o informacje na temat ich wykształcenia, miejsca pracy oraz stopnia zainteresowania historią. Pośrednio, w trakcie wywiadów, zostały zdobyte również informacje na temat innych osób, które współpracowały z badanymi przy tych działaniach.

Poniższą analizę oparłem przede wszystkim na jedenastu częściowo ustrukturyzowanych wywiadach z osobami bezpośrednio zaangażowanymi w obronę ulic Dąbrowszczaków oraz w popularyzowanie ich historii we współczesnej Polsce. Respondenci (9 mężczyzn i 2 kobiety) byli w wieku 
25-44 lat ${ }^{2}$. Temat dąbrowszczaków został poruszony również w większości pozostałych wywiadów prowadzonych z pracownikami IPN, ekspertami oraz z niektórymi przedstawicielami lokalnych samorządów (przede wszystkim z Warszawy, Gdańska i Olsztyna).

Informacje $z$ wywiadów uzupełniła systematyczna kwerenda przeprowadzona w prasie ogólnokrajowej („Gazeta Wyborcza”, „Rzeczpospolita”, „Nasz Dziennik”) oraz dodatkowa kwerenda w prasie lokalnej. W opisie dynamiki sporu o dąbrowszczaków przed rokiem 2016 znaczną pomoc stanowiła analiza dyskursu medialnego przeprowadzona przez Wojciecha Opiołę $\mathrm{w}$ książce Hiszpańska wojna domowa $w$ polskich dyskursach politycznych. Analiza publicystyki 1936-2015 (2016) oraz w studium Bartłomieja Różyckiego Dąbrowszczacy i pamięć o hiszpańskiej wojnie domowej w Polsce Ludowej (2013).

Została podjęta również obserwacja uczestnicząca dwóch wydarzeń związanych $z$ upowszechnianiem pamięci o dąbrowszczakach. Jednym była promocja książki Piotra Ciszewskiego Dąbrowszczacy. Na świecie szanowani, w Polsce poniżani (2018), drugim premiera w 2018 roku filmu Dariusza Zalegi pt. Pięśc $i$ dynamit. Gawęda o śląskich antyfaszystach w Hiszpanii.

\section{KONTEKST TEORETYCZNY: PAMIĘĆ — TOŻSAMOŚĆ — POLITYKA}

„Nie można zredukować polityki do rywalizacji o zasoby materialne; w rzeczy samej, wiele w niej dotyczy rywalizacji o zbiorową tożsamość, wliczając $w$ to często śmiertelne boje o znaczenie symboli wyrażających tę tożsamość" - twierdzą Myron Aronoff i Jan Kubik (2013, s. 24). Relacje między pamięcią, tożsamością oraz polityką są silne, a przy tym złożone. Na poziomie dyskursu aktorów politycznych możemy zaobserwować wzajemne warunkowanie się wszystkich tych elementów. Jest to być może konsekwencja temporalnego wymiaru tych relacji — ich przeszłości, teraźniejszości i przyszłości. Pamięć społeczna wyznacza kulturowe i moralne ramy, które służą do określenia sensu istnienia danej grupy, jej granic oraz warunków przynależności do niej (zob. Kwiatkowski 2008, s. 15-17; Fogu, Kansteiner 2006). Pamięć — podobnie jak zakorzeniona w wyobrażeniach o przeszłości tożsamość - pozwala interpretować teraźniejszość,

\footnotetext{
${ }^{2}$ Wprost przywołuję tutaj postacie siedmiu spośród wszystkich jedenastu respondentów. Są to osoby, które inicjowały określone działania lub miały największy wpływ na ich realizację. Ze względu na publiczny charakter tych działań ich imiona i nazwiska nie zostały zanonimizowane. Pozostałe cztery osoby również były w różnym stopniu zaangażowane w opisywane działania.
} 
wyznaczać ramy działania i formułować cele społeczne (Szacka 2006, s. 94; Misztal 2003, s. 133-139). Te ostatnie zaś w wymiarze praktycznym są realizowane poprzez politykę. Jeśli spojrzymy na tę relację od strony polityki i odwołamy się do klasycznej koncepcji Maksa Webera (1998) - polityki jako dążenia do udziału we władzy — to wpływ na kształt pamięci społecznej określającej tożsamość i legitymizującej działanie polityczne możemy postrzegać jako klucz do osiągnięcia i utrzymania tej władzy.

Pamięć społeczna jest zatem istotnym, choć wciąż często niedocenianym w studiach politycznych (Lipiński 2014, s. 30-32), czynnikiem sprawczym w polityce, wpływa bowiem na działania aktorów politycznych (March, Olsen 2005, s. 14-21). Jak zauważył Artur Lipiński (2014, s. 33): „[...] bez badań nad pamięcią niezwykle trudno wyobrazić sobie wiarygodną analizę politologiczną prowadzoną z perspektywy interpretatywnej. Jeśli praktyki tworzenia znaczeń (użycia idei, dyskursywnego konstruowania itp.) leżą $\mathrm{w}$ centrum zainteresowania podejść interpretatywnych, to badanie pamięci stać się musi nieodłącznym aspektem tych badań".

Docenienie roli kultury jako podstawowego instrumentarium społecznego (zawierającego symbole, normy, rytuały, dyskursy i światopoglądy) niesie daleko idące konsekwencje dla postrzegania jej znaczenia w rywalizacji o władzę i wpływa na sposób jej sprawowania. Jednocześnie dostrzeżenie, że jednostki nie są „więźniami” kulturowo narzuconych dążeń, lecz raczej „aktywnymi, czasami zręcznymi użytkownikami kultury”, posługującymi się nią w celu konstruowaniu własnych strategii działania (Swidler 1986, s. 277), kieruje uwagę na zmienność i elastyczność kultury oraz na to, jaki wpływ wywierają na nią aktorzy społeczni.

Włączenie problemów pamięci i tożsamości do analizy polityki wiąże się przede wszystkim $z$ wzięciem pod uwagę pełnionych przez nie funkcji: „zasobów” i „ograniczeń” politycznych (resources and constraints) (Aronoff, Kubik 2013, s. 66-67). Jak zauważył David Laitin (1986, s. 11), z jednej strony „[...] kultura wyznacza priorytety polityczne” jednostek, ale $z$ drugiej strony - jednostki biorące udział w grze politycznej starają się wpływać na kulturę, gdy „kulturowa tożsamość staje się zasobem politycznym".

Po pierwsze, oznacza to, że pamięć i tożsamość zapewniają zasoby umożliwiające lub ułatwiające podejmowanie określonych działań politycznych. Wybiórcza i w określony sposób interpretowana pamięć o przeszłych wydarzeniach ogranicza horyzont oczekiwań i kształtuje zakres tego, co społecznie jest dopuszczalne, a co niedopuszczalne. Ponadto pamięć społeczna koncentruje się na powszechnie uznawanych i rozpoznawanych W danej społeczności przedmiotach sporu (points of concern) (Laitin 1986, 
s. 29), wokół których co jakiś czas ogniskuje się debata publiczna i które stanowią dla aktorów politycznych aktualny punkt samookreślenia. Specyficzny kanon bohaterów (i antybohaterów) zapewnia określony repertuar wzorów działania społecznego, a określona narracja o przeszłych dziejach danej grupy zawiera hierarchię postaw i wartości. Umiejętne odwołanie się do jednych i drugich pozwala zarówno uzyskać mobilizację społeczną, jak i zdobyć społeczną aprobatę i kapitał zaufania. Po drugie, zastany kształt pamięci społecznej również ogranicza aktorów społecznych w ich działaniach politycznych, sprawiając, że określone symbole i hasła uzyskują większą skuteczność mobilizacyjną lub powodują mniejszy opór społeczny niż inne ${ }^{3}$.

Pamięć i związana $z$ nią tożsamość są zatem materią w istotny sposób wpływającą na treść i sposób prowadzenia polityki. Politycy, kierując się swoim interesem oraz kulturowo definiowanymi dążeniami, zarówno dostosowują swoje działania do tych uwarunkowań, jak i starają się wpływać na to „co” i w ,jaki sposób” jest pamiętane, tak aby przekształcić tożsamość danej grupy odpowiednio do własnych przekonań i celów.

W tym wymiarze jedno $z$ największych ograniczeń dla aktorów politycznych stanowi ogromne zróżnicowanie pamięci w ramach danego społeczeństwa oraz występujący w nim pluralizm tożsamości. Dlatego też: „polityka polega na dążeniu do oswojenia nieskończoności tożsamości. Jest to próba takiego hegemonizowania tożsamości, aby uporządkować ją w silne programowe oświadczenie. Jeśli tożsamość jest zdecentralizowana, polityka dotyczy próby stworzenia centrum" (Dirks, Eley, Ortner 1994, s. 32). Przy czym wydaje się słuszne założenie, że w im większym stopniu mobilizacja społeczna danej siły politycznej oparta jest na polityce tożsamościowej (identity politics), tym silniejsza jest w niej potrzeba ujednolicenia społecznych pamięci i dążenie do promocji jednego modelu przynależności (Zenderowski 2011). Zjawisko to zachodzi niezależnie, czy dana siła polityczna odwołuje się do nacjonalizmu grupy większościowej, czy też występuje w imię obrony interesów grup mniejszościowych (Yiftahel 2006, s. 11-47).

Ujednolicenie tożsamości społecznej jest zatem drogą do osiągnięcia stanu hegemonii kulturowej. Jan Kubik (1994, s. 11) definiuje ją jako „taki aspekt relacji władzy, który jest wytwarzany lub gwarantowany nie przez

${ }^{3}$ Wymowne przykłady ograniczeń, jakie nakłada kultura na interesy, przekonania i działania aktorów społecznych, nawet w wymiarze polityki międzynarodowej (często postrzeganej jako podporządkowana chłodnej, racjonalnej kalkulacji) analizowali na przykład autorzy studiów w zbiorze pod redakcją Petera Katzensteina The Culture of National Security: Norms and Identity in World Politics (1996). 
zewnętrzny przymus, ale przez akceptację (nawet jeśli fragmentaryczną i nie w pełni świadomą) definicji rządzących przez rządzonych". Skrajną formą sukcesu tej polityki jest uzyskanie wyłącznej ideologicznej dominacji w polu kultury, gdyż „[...] legitymizacja władzy jest tak zakorzeniona w kulturowych definicjach rzeczywistości, że są one brane za pewnik jako formy codziennej świadomości, nawyków i zwyczajów" (Aronoff, Kubik 2013, s. 81).

Jedną $z$ dróg uzyskiwania przez rządzących hegemonii na polu kultury jest ingerencja w pamięć społeczną poprzez, z jednej strony, kształtowanie i promowanie zinstytucjonalizowanej pamięci oficjalnej, a $z$ drugiej strony - wypieranie $z$ niej wszystkich elementów mogących służyć do jej podważenia. Ernest Gellner (1987, s. 6), przywołując opinię Ernesta Renana, wskazał, że: „wspólne wspomnienia i współdzielona przeszłość jest jednym z elementów, które łączą ludzi i pomagają sformować naród, ale [...] to podzielana amnezja, wspólnotowe zapominanie [collective forgetfulness], jest przynajmniej równie istotne dla pojawienia się tego, co my obecnie uznajemy za naród".

Manipulacja pamięcią $\mathrm{w}$ celach politycznych wydaje się jednak znacznie starsza niż naród. „Poszczególne epoki - jak stwierdził ostatnio Rafał Chwedoruk (2018, s. 20) - zajmowały inne stanowisko względem historii, lecz w każdej próbowano w nią ingerować ze względów politycznych. Instrumentalne podejście do historii towarzyszyło jej od starożytnych początków". Jednak jeśli polityka historyczna jako zjawisko jest elementem stałym, a być może nawet koniecznym, to jej forma oraz zakres ingerencji w pamięć społeczną mogą być bardzo różne.

Paul Connerton (2008, s. 60) wymienił siedem typów zapominania, z których pierwszy, mający najbardziej polityczny charakter, określił jako „represyjne wymazywanie” (represive erasure). Jest to sytuacja, w której władze świadomie ingerują w pamięć społeczną zarówno w celu „zatarcia” wydarzeń przeczących historycznej ciągłości, jak i stworzenia narracji o takim historycznym „zerwaniu” - nowym początku. Piotr T. Kwiatkowski zaś, analizując zjawisko społecznej niepamięci, wyróżnił bierne i aktywne sposoby zapominania. Do tej drugiej grupy zaliczył następujące metody: „1) zaprzeczanie, że określone stany faktyczne zaistniały w przeszłości; 2) zacieranie śladów pewnych faktów z przeszłości; 3) cenzurowanie stwarzanie przeszkód w badaniu i publicznym omawianiu niektórych faktów z przeszłości; 4) wymierzanie sprawiedliwości" (Kwiatkowski 2009, s. 107). Ta kategoryzacja obejmuje szeroki repertuar zabiegów, po które w różnym stopniu może sięgnąć władza w celu zarządzania pamięcią społeczną. 
W praktyce zdobycie i utrzymywanie hegemonii kulturowej, w tym panowanie nad pamięcią społeczną, jest niezwykle trudne, nawet jeśli ma się do dyspozycji sprawny i zdyscyplinowany aparat przymusu i pełną kontrolę nad instytucjami kultury (Aronoff, Kubik 2013, s. 82). Wynika to, po pierwsze, $z$ nieuchronnej społecznej różnorodności, po drugie, z uczestnictwa w grze politycznej różnych aktorów (Ochman 2017), a po trzecie, z nieuniknionych przemian pokoleniowych. Zwłaszcza ostatni aspekt jest interesujący ze względu na podjęty tu temat. Współczesne badania (Schuman, Corning 2011; Corning 2010; Schuman, Rodgers 2004) potwierdzają założenia Karla Mannheima (1952) dotyczące znaczenia zmiany pokoleniowej w przemianach społecznych i kulturowych.

Pokolenie jest rozumiane jako zbiór jednostek urodzonych w tym samym historycznym i kulturowym kontekście, które w okresie dojrzewania nabyły podobnych, charakterystycznych dla danego czasu doświadczeń. Odrębność poszczególnych pokoleń jest zatem zakorzeniona w wyjątkowości podzielanych wspomnień z młodości. Członków pokoleń ukształtowanych przez wspólne doświadczenia historyczne — „wspólnot percepcji”, jak pisze Jeffrey Olick (1999, s. 339) - cechują „[...] pewne charakterystyczne sposoby myślenia, doświadczenia oraz rodzaje historycznie istotnych działań" (por. Mannheim 1952, s. 291). Kolejne pokolenia, wyposażone we własny bagaż formacyjnych doświadczeń, redefiniują kategorie świata społecznego i stają się tym samym aktywnymi agentami zmiany społecznej (Wangler 2012, s. 21).

Zmiana pokoleniowa ma wpływ na konstrukcję pamięci społecznej (Gryta 2019). Nowe pokolenie, stopniowo zajmujące miejsce poprzedniego w instytucjach państwa oraz w przestrzeni kultury i sztuki, może rzucić wyzwanie dotychczasowemu porządkowi pamięci niezależnie od tego, czy ten porządek utrzymywany jest $w$ ramach pewnego konsensu społecznego, czy też przemocą przez władzę autorytarną. Dobrym przykładem pierwszej sytuacji jest zerwanie $z$ milczeniem o tragedii wojny domowej w Hiszpanii przez „pokolenie wnuków” jej uczestników (Assmann 2012; Aguilar, Ramirez-Barat 2016); drugiej - wyzwanie rzucone oficjalnej pamięci historycznej PRL przez młode pokolenie Polaków w latach osiemdziesiątych (Kubik 1994).

\section{KONTEKST HISTORYCZNY}

Fenomen wojny hiszpańskiej z lat 1936-1939 polega na tym, że chociaż rozpoczęła się ona jako wojna domowa, to prowadzona i relacjonowana była jako wojna o Europę. Szacuje się, że brało w niej udział około 5 tys. oby- 
wateli Polski. Większość z nich stanowili robotnicy przebywający wówczas na emigracji, między innymi we Francji i w Belgii. Bezpośrednio z Polski dotarło około tysiąca ochotników (Różycki 2013, s. 167). Polacy stanowili jedną z najliczniejszych grup narodowościowych wchodzących w skład Brygad Międzynarodowych. To od nazwy jednej z nich, XIII Brygady im. Jarosława Dąbrowskiego, do wszystkich polskich ochotników przylgnęło miano dąbrowszczaków.

W ciągu czterech lat wojny do oddziałów organizowanych przez Międzynarodówkę Komunistyczną (Komintern) weszło około 35 tys. ochotników z kilkudziesięciu krajów świata. Walczyli oni po stronie republikańskiego rządu w Madrycie popieranego przez szeroki lewicowy Front Ludowy współtworzony zarówno przez umiarkowanych republikanów, jak i komunistów czy anarchistów. Przeciwko sobie mieli wojska zbuntowanych generałów składające się głównie z około 75 tys. żołnierzy hiszpańskich z Maroka, wspieranych przez 17 tys. żołnierzy niemieckich i 75 tys. włoskich (Opioła 2016, s. 47). Wojna miała więc charakter międzynarodowy i od początku przedstawiana była jako wielki konflikt ideologiczny. Przy czym w zależności od sympatii obserwatora albo jako spór sił postępu i demokracji z faszyzmem i reakcją, albo walka między rewolucjonistami, komunistami i antyklerykałami a obrońcami wiary i porządku (Opioła 2016, s. 8).

W Polsce agitację na rzecz pomocy Republice prowadziła przede wszystkim należąca do Kominternu Komunistyczna Partia Polski, ale sprzyjała i organizowała dla niej pomoc również Polska Partia Socjalistyczna oraz niektóre związki zawodowe. Znalazło to wyraz w przynależności partyjnej ochotników. Szacuje się, że około połowy z nich stanowili komuniści, bardzo duża była również grupa osób bezpartyjnych, mniej było socjalistów, członków Bundu czy innych grup lewicowych (Opioła 2016, s. 64-65). Po stronie buntu generałów opowiedziały się Stronnictwo Narodowe oraz Kościół katolicki (Różycki 2013, s. 172). Wiadomo o nielicznych Polakach, którzy wzięli udział w tej wojnie także po stronie Franco (Różycki 2013, s. 167).

W trakcie wojny zginąć miało ok 2-3 tys. dąbrowszczaków (Różycki 2013, s. 170). Po przegranej walce reszta powróciła do swych domów we Francji lub została internowana w obozach na terenie Francji i Afryki Północnej (Opioła 2016, s. 65). Na mocy ustawy z 1920 roku za przystąpienie do służby w obcym wojsku karani byli odebraniem polskiego obywatelstwa. Po roku 1939 wzięli oni ponownie udział w walce, bardzo często angażując się w działalność konspiracyjną na terenach okupowanych przez III Rzeszę. Po zakończeniu drugiej wojny światowej do kraju powróciło około tysiąca dąbrowszczaków, wielu z nich weszło do struk- 
tur powstającego nowego państwa polskiego, w tym kilkadziesiąt zajęło wysokie stanowiska w ministerstwach, służbach wywiadowczych, wojsku i służbach bezpieczeństwa (Opioła 2016, s. 66). Ich legenda została wykorzystana w polityce historycznej PRL. Jak pisze Bartłomiej Różycki (2013, s. 173): „[...] fakt stawienia czoła faszyzmowi w okresie, w którym w Europie dominował duch appeasementu, a w Polsce złudna nadzieja na uratowanie pokoju, sprawił, że przykład Dąbrowszczaków stanowił dla władzy ludowej niezwykle cenny materiał propagandowy".

\section{DĄBROWSZCZACY W POLITYCE HISTORYCZNEJ PRL}

Wojna domowa w Hiszpanii zajmuje szczególne miejsce w polskim kanonie historycznym. W znacznym stopniu należy do wydarzeń zapomnianych, o czym może świadczyć między innymi brak jakichkolwiek popularnych odniesień kulturowych na jej temat, które powstałyby w Polsce po 1989 roku. Również te $z$ okresu PRL nie utrwaliły się $\mathrm{w}$ polskiej świadomości kulturowej. Mimo to jednak pamięć o tej wojnie i udziale w niej polskich ochotników co jakiś czas z wyraźną regularnością odżywa w polskiej debacie publicznej prowadzonej zarówno przez historyków, jak i polityków czy dziennikarzy.

Analiza przedwojennej polskiej prasy pozwoliła stwierdzić Wojciechowi Opiole (2016, s. 250), że w latach 1936-1939 „[...] hiszpańska wojna domowa (a szczególnie jej zideologizowany obraz w prasie) była polityczną soczewką, przez którą każdy z tych nurtów [politycznych - J.W.] przyglądał się ważnym dla siebie a zagrożonym wartościom (demokracji, wolności, narodowi, religii)”. Ten pluralizm narracji załamał się wraz z zakończeniem drugiej wojny światowej. Po roku 1945 historia wojny w Hiszpanii oraz losy dąbrowszczaków podporządkowano oficjalnej polityce historycznej Polski Ludowej. Zostali w pełni zrehabilitowani. Już w 1945 roku powstał kombatancki Związek Uczestników Walk o Wolność Hiszpanii w latach 1936-1939, który w 1949 roku wszedł w skład skupiającego wszystkich weteranów Związku Bojowników o Wolność i Demokrację (ZBoWiD) (Różycki 2013, s. 173-174). Przywrócono im polskie obywatelstwo oraz uznano zdobyte przez nich stopnie wojskowe. Zgodnie z rozkazem ministra obrony narodowej z 1949 roku uhonorowano odbytą przez nich służbę wojskową w Hiszpanii, a w poczet walki przeciwko „armiom faszystowskim” zaliczono również czas spędzony w obozach internowania. Pod względem przywilejów zostali zrównani z żołnierzami ludowego Wojska Polskiego i późniejszych Sił Zbrojnych PRL (Różycki 2013, s. 198). Niektórzy z nich weszli do aparatu bezpieczeństwa nowe- 
go państwa, kilku zajęło wysokie stanowiska w aparacie władzy (Różycki 2013, s. 201-202).

W Polsce Ludowej pamięć o dąbrowszczakach stała się częścią oficjalnej polityki historycznej, a polscy żołnierze Brygad Międzynarodowych, przede wszystkim postać generała Karola Świerczewskiego, zostali włączeni do panteonu bohaterów. Stanowić mieli uosobienie oddania ideowego i wojennego męstwa. Zostali wpisani w narodowy kanon romantycznych wojowników „o wolność naszą i waszą”, a zarazem ucieleśniali międzynarodowy lewicowy front walki z faszyzmem. Powstało wiele dzieł budujących legendę "generała Waltera”, między innymi w 1948 roku popularna książka dla dzieci O człowieku, który się kulom nie kłaniał autorstwa Janiny Broniewskiej czy poświęcony mu film Żotnierz zwycięstwa z 1953 roku w reżyserii Wandy Jakubowskiej. Kombatantów wojny domowej w Hiszpanii uhonorowano w przestrzeni publicznej, między innymi przez nadanie ulicom w wielu miejscowościach ich imienia. Ustanowiono także pamiątkowe odznaczenie państwowe: Medal „Za waszą wolność i naszą”, na rewersie którego znalazł się „generał Walter” ${ }^{4}$, a do listy lektur licealnych została włączona powieść Ernesta Hemingwaya Komu bije dzwon.

Jednakże romantyczna „hiszpańska legenda” antyfaszyzmu oraz wyjątkowy status dąbrowszczaków w PRL często nie miały odzwierciedlenia w losach weteranów wojny w Hiszpanii. Wielu z nich spotkało się z szykanami nowych władz, jeżeli wykryto ich ideową nieprawomyślność lub niedostosowanie do warunków społecznych i oczekiwań politycznych. Historia dąbrowszczaków mimo wszystko znalazła się na marginesie polityki historycznej PRL. Rocznice związane z wojną w Hiszpanii, „poza kilkoma wyjątkami, [...] pozostawały nieznaczącymi datami w kalendarzu, jednymi z licznych okoliczności, przy których w oficjalnych przemówieniach można było nawiązać do stałych elementów socjalistycznego dyskursu na temat sytuacji międzynarodowej: wojny w Wietnamie, amerykańskiego imperializmu, odradzania się faszystowskich i militarystycznych tendencji w RFN. Autoteliczna wartość wspomnień o Hiszpanii była właściwie żadna" (Różycki 2013, s. 209).

\section{DĄBROWSZCZACY W PAMIĘCI SPOŁECZNEJ W LATACH 1989-2016}

Upadek systemu politycznego PRL odbił się dotkliwie na pamięci społecznej o odległej z polskiej perspektywy hiszpańskiej wojnie. Po roku

${ }^{4}$ Dekret z dnia 18 października 1956 r. o ustanowieniu medalu „Za waszą wolność i naszą" (Dz.U. z 1956 r. nr 46, poz. 207). 
1989 legenda dąbrowszczaków została radykalnie podważona, zarówno w wyniku procesu odbrązawiania komunistycznej propagandy, jak i na skutek zdecydowanego ideologicznego antykomunizmu narracji części środowisk solidarnościowych i postsolidarnościowych. W 1990 roku nowo wybrany parlament pracował nad projektem tzw. ustawy kombatanckiej mającej na celu odebranie specjalnych uprawnień osobom związanym w latach 1944-1956 z państwowym aparatem represji. W ramach pracy nad tą ustawą część posłów dążyła do odebrania przywilejów kombatanckich także żyjącym jeszcze dąbrowszczakom. W rezultacie tych zabiegów zostali oni wyłączeni z grupy kombatantów, ale na skutek sprzeciwu części senatorów nie pozbawiono ich otrzymywanych $z$ tego tytułu świadczeń. Temat przywilejów kombatanckich dąbrowszczaków podnoszony był w parlamencie także w latach 1993-1994, w 1997 oraz 2007 roku. Za każdym razem wywoływał znaczące emocje zarówno w trakcie debaty parlamentarnej, jak i w relacjonującej ją prasie (Opioła 2016, s. 238-240). Wraz z upływem czasu powracająca dyskusja traciła stopniowo choćby pozory jakiegokolwiek realnego znaczenia — w 2007 roku zaledwie dwadzieścia pięć osób pobierało jeszcze emerytury kombatanckie z tytułu udziału w wojnie domowej w Hiszpanii (Bukalska 2007).

Działania parlamentarne wymierzone $\mathrm{w}$ uprawnienia kombatanckie dąbrowszczaków dla polskiej prawicy były raczej środkiem do symbolicznego rozliczenia się z lewicowym mitem wojny domowej niż ostatecznym celem. W części złożonego wewnętrznie obozu prawicy wynikało to nie tylko z potępienia republikańskiej strony tego konfliktu, ale też z admiracji dla haseł głoszonych przez stronę frankistowską. Hiszpania Franco była przedstawiana w tym kręgu jako silne, autorytarne, katolickie i zdecydowanie antykomunistyczne państwo. Jako argumenty służyły też: poparcie Franco dla polskiego obozu niepodległościowego w PRL, utrzymywanie przezeń stosunków dyplomatycznych z Rządem RP na uchodźctwie czy ochrona Żydów na terytorium Hiszpanii przed Holokaustem. Według Wojciecha Opioły (2016, s. 229-238), który prześledził debatę prasową z lat 1989-2015, zdecydowanie profrankstowskie wypowiedzi głosiły takie osoby jak Stefan Kisielewski, Stefan Niesiołowski, Maciej Giertych, Jacek Bartyzel czy Adam Wielomski. Konserwatywno-katolicką narrację na temat wojny domowej w Hiszpanii wsparli również Marek Jan Chodakiewicz W opracowaniu Zagrabiona pamięć (1997) oraz Paweł Skibiński w książce Państwo generała Franco. Ustrój Hiszpanii w latach 1936-1967 (2004).

Debata na temat polskiej pamięci o wojnie domowej w Hiszpanii ponownie pojawiła się na początku XXI wieku. Dojście do władzy w latach 2005-2007 prawicowej koalicji Prawa i Sprawiedliwości, Ligi Polskich Ro- 
dzin i Samoobrony zbiegło się ze zmianą kierunku polityki historycznej w Hiszpanii. W związku z siedemdziesiątą rocznicą wybuchu wojny domowej socjalistyczny rząd José Luisa Rodrígueza Zapatero rok 2006 ogłosił rokiem pamięci historycznej. Wprowadzona $\mathrm{w}$ życie ustawa o pamięci historycznej (Ley de Memoria Histórica) zerwała z wcześniejszą polityką pojednania (lub zdaniem niektórych amnezji; Palloma 2002) w imię zgody narodowej. Miała ona na celu oddanie sprawiedliwości ofiarom wojny oraz powojennej dyktatury zarówno w wymiarze moralnym, jak i finansowym. Zakładała ekshumację pochowanych $\mathrm{w}$ masowych grobach ofiar frankistów oraz rozliczenie się ze spuścizną po reżimie Franco, między innymi poprzez swego rodzaju „defrankoizację” przestrzeni publicznej (Biernacka 2017), utworzenie Centrum Dokumentacji Pamięci Historycznej oraz przyznanie obywatelstwa hiszpańskiego członkom Brygad Międzynarodowych (Keller 2012).

Działania rządu hiszpańskiego wywołały w Polsce lawinę artykułów prasowych, które na nowo rozgrzały debatę na temat wojny domowej (Opioła 2016, s. 234). Jednak poza nielicznymi wyjątkami w środowiskach lewicowych polityka historyczna Zapatero spotkała się z krytyką środowisk zarówno liberalnych, które przyrównały ją do polityki historycznej „PiS, IPN i obozu katolicko-narodowego” (Stasiński 2010), jak i konserwatywnych, które oceniały ją jako emanację konfliktogennego, stronniczego upolitycznienia historii (Tryc-Ostrowska 2010). Krytyka ta nie ograniczyła się do łam prasowych. W 2006 roku Maciej Giertych jako eurodeputowany z Ligi Polskich Rodzin wygłosił w Brukseli mowę pochwalną na część roli, jaką generał Franco - jego zdaniem — odegrał w pokonaniu komunizmu w Hiszpanii. Wkrótce, w 2007 roku prawicowy rząd w Polsce podjął ponowne działania na rzecz potępienia polskich uczestników wojny domowej w Hiszpanii, odebrano im przywileje kombatanckie. Był to tylko jeden $z$ elementów antykomunistycznej polityki historycznej prowadzonej w tym czasie przez obóz rządzący (Ochman 2010).

Niezależnie od oceny działań rządu Zapatero działania polskiego rządu spotkały się $z$ gwałtowną reakcją środowiska liberalnego związanego z dawną opozycją demokratyczną oraz z „Gazetą Wyborczą”, w tym potomków dąbrowszczaków oraz członków drużyn walterowskich. Byli oni $\mathrm{W}$ stanie $\mathrm{w}$ szybkim tempie zorganizować szerokie wsparcie medialne w obronie dąbrowszczaków. Teksty podważające słuszność rozliczeń z polskimi ochotnikami znalazły się między innymi w „Tygodniku Powszechnym” (Bukalska 2007) oraz w „Gazecie Wyborczej”, która opublikowała też informacje o proteście hiszpańskiego senatu przeciwko planom polskiego rządu (MAS 2007). Redaktor naczelna „Zeszytów Literackich” Bar- 
bara Toruńczyk, prywatnie córka dąbrowszczaka, przygotowała Apel Antygony - list otwarty w sprawie Dąbrowszczaków, skierowany przeciwko szkalowaniu dobrego imienia i wymazywaniu z pamięci polskich członków Brygad Międzynarodowych. Został on przedrukowany przez „El País” i podpisany przez kilkaset osób, w tym wielu polskich intelektualistów związanych ideowo i pokoleniowo z tym środowiskiem. Dąbrowszczacy zostali przedstawieni w nim jako „ochotnicy polscy, [którzy] szli na wojnę hiszpańską poderwani bojowym wezwaniem europejskich demokratów: No pasaran - nie godząc się na faszyzm w Europie”, jako ludzie, „którzy ocalili honor europejskiej demokracji i politycznego idealizmu" (Toruńczyk 2007). Już wkrótce na łamach „Rzeczpospolitej” dąbrowszczacy zostali odmalowani piórami prawicowych publicystów jako odpowiedzialni za „zbrodnie na jeńcach, eksterminację duchownych, rozstrzeliwania nauczycieli, prawników, urzędników państwowych i innych «burżujów»" (Ziemkiewicz 2007) oraz jako „wierni żołnierze Stalina”, ,jeźdźcy komunistycznej apokalipsy” oraz „filary zbrodniczego systemu” (Gontarczyk 2007).

Jedną z konsekwencji zakwalifikowania dąbrowszczaków do kategorii komunistów było wpisanie ich na listę patronów ulic i placów, których nazwy powinny ulec zmianie. Już w latach 2007-2008 ówczesny prezes IPN Janusz Kurtyka rozpoczął akcję wysyłania pism do prezydentów i burmistrzów miast $\mathrm{w}$ Polsce $\mathrm{w}$ celu przekonania ich do zmiany niewłaściwych nazw ulic i placów, w tym tych upamiętniających dąbrowszczaków (Opioła 2014, s. 79-80). Z wywiadów przeprowadzonych z byłymi i obecnymi pracownikami IPN wynika, że negatywne doświadczenia Kurtyki z dyskusji z samorządowcami skłoniły kierownictwo Instytutu do poszukiwania innych, systemowych metod w celu „uporządkowania przestrzeni symbolicznej w kraju" (jak określił dekomunizację jeden z respondentów). W latach 2014-2015 radni Prawa i Sprawiedliwości podejmowali próby zrealizowania planów IPN na poziomie samorządów 5 .

Ustawa $z$ dnia 1 kwietnia 2016 r. o zakazie propagowania komunizmu lub innego ustroju totalitarnego przez nazwy jednostek organizacyjnych, jednostek pomocniczych gminy, budowli, obiektów i urządzeń użyteczności publicznej oraz pomniki - uchwalona przez Sejm prawie jednogłośnie (przy jednym wstrzymującym się głosie) — głosi, że nie można

${ }^{5}$ W Warszawie inicjatywę na rzecz „dekomunizacji” nazw ulic (w tym zmiany nazwy ulicy Dąbrowszczaków) podjęła przede wszystkim warszawska radna z rekomendacji PiS Olga Johann. Jako wiceprzewodnicząca Komisji ds. Nazewnictwa Miejskiego dążyła ona do wcielenia w życie rekomendacji IPN przez nadanie jednej z warszawskich ulic nazwy „Żołnierzy Wyklętych" oraz usunięcie z ulicznych tablic ponad trzydziestu innych patronów (Osowski 2016). 
w przestrzeni publicznej „upamiętniać osób, organizacji, wydarzeń lub dat symbolizujących komunizm lub inny ustrój totalitarny, ani w inny sposób takiego ustroju propagować" 6 . Na mocy tej ustawy IPN otrzymał wyłączne kompetencje do opiniowania, czy dany patron symbolizuje lub propaguje system komunistyczny, czy też nie. Samorządom został wyznaczony okres dwunastu miesięcy na wprowadzenie sugerowanych przez IPN zmian. W razie niewypełnienia przez nie tego obowiązku kompetencje do zmiany patronów miał przejąć miejscowy wojewoda. Takie rozwiązanie ucinało wszelkie spekulacje oraz miało zapewnić skuteczność i nieodwołalność decyzji.

Na stronie internetowej Instytutu Pamięci Narodowej pojawił się wykaz 146 „przykładowych nazw ulic” wskazanych przez IPN jako podlegające tzw. ustawie dekomunizacyjnej ${ }^{7}$. W notce uzasadniającej usunięcie dąbrowszczaków z grona odpowiednich patronów określono ich jako „realizatorów polityki stalinowskiej na Półwyspie Iberyjskim”, z których „większość [...] dążyła do budowy w Hiszpanii państwa stalinowskiego”, przywołany został również fakt, że stali się oni „zapleczem kadrowym dla powstających w centralnej Polsce oddziałów komunistycznej Gwardii Ludowej PPR". Autor ani data stworzenia tej notki nie są znane.

Można przypuścić, że nowe władze oraz kierownictwo IPN liczyło się $z$ oporami przy realizacji tej ustawy, wydaje się jednak, że ich skala przekroczyła znacznie te oczekiwania. Niechęć zarówno do formy dekomunizacji, jak i sposobu jej rozumienia przez IPN skłoniły do oporu w wielu miejscach w Polsce władze samorządowe broniące swej suwerenności w zakresie upamiętnień oraz środowiska społeczników broniące patronów i symboli istotnych dla tożsamości społeczności lokalnych. W obronie dąbrowszczaków stanęli młodzi przedstawiciele wielu niewielkich i rozproszonych środowisk lewicowych. $Z$ czasem byli coraz lepiej zorganizowani. Skala oraz skuteczność podjętych przez nich działań wprowadziły zupełnie nową jakość w publicznej debacie na temat tych spornych patronów.

\section{OBRONA DĄBROWSZCZAKÓW PRZED DEKOMUNIZACJĄ}

W dniu 1 marca 2016 r. Zuzanna Hertzberg - malarka, twórczyni instalacji i performansów, wnuczka jednego z dąbrowszczaków - w asyście kilkunastu osób złożyła trójkolorowy wieniec przy Grobie Nieznanego

${ }^{6}$ Dz.U. RP z 2016 r. poz. 744.

7 „Nazwy do zmiany” (https://ipn.gov.pl/pl/upamietnianie/dekomunizacja/zmiany-naz w-ulic/nazwy-ulic/nazwy-do-zmiany). 
Żołnierza w Warszawie. Była to osiemdziesiąta rocznica wybuchu wojny domowej w Hiszpanii. Wieniec uformowany w czerwono-żółto-fioletowe pasy ozdobione trójramienną czerwoną gwiazdą symbolizował flagę Brygad Międzynarodowych biorących udział w tej wojnie po stronie sił broniących Republiki. Podobnie jak inne delegacje w tym miejscu, niewielki pochód ruszył spod pomnika Marszałka Józefa Piłsudskiego. W dłoniach uczestników powiewały zrekonstruowane proporce kompanii Naftalego Botwina oraz batalionu Adama Mickiewicza, w których walczyli pochodzący z Polski ochotnicy. Złożeniu kwiatów u stóp pomnika towarzyszyły słowa Hertzberg: „W hołdzie ochotnikom wolności, członkom XIII Międzynarodowej Brygady Dąbrowszczaków". Następnie wyrecytowany został wiersz Władysława Broniewskiego. W odpowiedzi, zgodnie z protokołem, żołnierze pełniący uroczystą wartę przy tym najważniejszym polskim miejscu pamięci narodowej prezentowali broń i zasalutowali przybyłym.

Złożenie wieńca było artystycznym performansem pt. „Dąbrowszczacy — wyklęci spośród wyklętych", za pomocą którego Hertzberg zamierzała podnieść kwestię zarówno własnej tożsamości, jak i tożsamości narodowej, z której pamięć o dąbrowszczakach ulegała, jej zdaniem, stopniowemu wymazywaniu ${ }^{8}$. Wybór miejsca był znaczący - to z Grobu Nieznanego Żołnierza na początku lat dziewięćdziesiątych została usunięta tablica upamiętniająca bitwy dąbrowszczaków w Hiszpanii (o Madryt, pod Guadalajarą oraz nad Ebro). Sprawozdanie $z$ tego wydarzenia pojawiło się tylko w niektórych mediach, jednak znalazło ono szeroki oddźwięk wśród przedstawicieli tzw. młodej lewicy w Polsce. Z wywiadów wynika, że zostało potraktowane jako inspiracja i zachęta do publicznego działania w imię obrony pamięci o dąbrowszczakach. Hertzberg otrzymała bardzo silny odzew również od zagranicznych stowarzyszeń „Przyjaciół Brygad Międzynarodowych".

Na kolejnym etapie swoich poszukiwań artystyczno-ideowych Hertzberg podjęła temat uczestnictwa kobiet w wojnie domowej w Hiszpanii. Pracując nad materiałem archiwalnym i poszukując sposobu artystycznego wyrażenia zebranych informacji, artystka przygotowała wystawę pt. „Ochotniczki wolności”. Ma ona formę sześciu skrzynek — obiektów pamięci poświęconych siedmiu kobietom, polskim Żydówkom uczestniczących w tej wojnie. Materialną prezentację uzupełniają opowiadane przez Hertzberg biografie tych kobiet ${ }^{9}$. Wystawa prezentowana była pod-

8 http://www.zuzannahertzberg.com/portfolio/wykleci-wsrod-wykletych-dabrowszczacy/

${ }^{9}$ http://www.zuzannahertzberg.com/portfolio/volunteers-for-freedom/ 
czas wielu festiwali i wydarzeń artystycznych w Polsce, między innymi w 2019 roku na ekspozycji Muzeum Sztuki Nowoczesnej.

Rok później, w trakcie festiwalu artystycznego „Warszawa w Budowie” zorganizowanego na placu Defilad przez Muzeum Sztuki Nowoczesnej, Hertzberg zrealizowała kolejny performans poświęcony dąbrowszczakom pt. „Nomadyczna pamięć” ${ }^{10}$. Na opuszczonym głazie, do którego przed rokiem 1989 przykręcona była tablica upamiętniająca powstanie Komunistycznej Partii Polski, przymocowała zaprojektowaną przez siebie tablice z napisem: „Dąbrowszczakom walczącym w wojnie z faszyzmem w Hiszpanii w latach 1936-1939". Podczas uroczystości odsłonięcia tablicy powiedziała: „Ten pomnik to nie tylko próba oddania hołdu Dąbrowszczakom, ale też ostrzeżenie. Na całym świecie odradzają się postawy faszystowskie i ksenofobiczne. Pamiętajmy o idealizmie politycznym, reprezentowanym przez tych, którzy pojechali do Hiszpanii, by walczyć z puczem militarnym generała Franco" (Wieczorkiewicz 2017). Jak stwierdziła, inspirację zaczerpnęła $z$ obserwacji obchodów pierwszomajowych w Göteborgu w Szwecji, które co roku rozpoczynają się pod tamtejszym pomnikiem poświęconym Brygadom Międzynarodowym. Poszukując miejsca trwałego upamiętnienia polskich ochotników w Hiszpanii, odkryła ten symbolicznie opuszczony głaz znajdujący się w samym centrum Warszawy. Wykreowała $\mathrm{w}$ ten sposób, na krótki moment, miejsce pamięci, którego przedtem nie było.

Piotr Ciszewski (39 lat, lewicowy działacz społeczny ${ }^{11}$ ) swą popularną książkę historyczną pod tytułem Dąbrowszczacy. Na świecie szanowani, w Polsce poniżani, wydaną przez czasopismo „Przegląd” w serii Historia bez IPN, rozpoczął od słów: „Dąbrowszczacy toczą dziś w Polsce kolejną bitwę. Tym razem nie znajdują się pod ostrzałem dział dostarczonych generałowi Franco przez Hitlera i Mussoliniego, lecz propagandy Instytutu Pamięci Narodowej" (Ciszewski 2018, s. 9). Praca ta, oprócz przybliżenia zdarzeń poprzedzających wybuch wojny domowej oraz opisania samego konfliktu, w blisko połowie składa się z 30 biogramów przygotowanych przez autora na podstawie materiałów archiwalnych (Ciszewski 2018, s. 229-401). W rozmowie Ciszewski powiedział, że zasadnicze znaczenie przy poszerzaniu wiedzy o wojnie domowej oraz zbieraniu materiałów do książki

\footnotetext{
10 http://www.zuzannahertzberg.com/portfolio/nomadic-memory/

11 Poza działalnością społeczną (m.in. w obronie eksmitowanych lokatorów) Ciszewski bardzo aktywnie uczestniczy w upowszechnianiu wiedzy o historycznych patronach lewicy, prowadząc stronę „Historia Czerwona” na portalu społecznościowym Facebook. Jest również członkiem Grupy Rekonstrukcji Historycznej Guerra Civil.
} 
miało dla niego nawiązanie kontaktów z osobami w innych krajach kultywującymi pamięć o Brygadach Międzynarodowych. W podobny sposób losy dąbrowszczaków przedstawiono $\mathrm{w}$ jednym $\mathrm{z}$ numerów kwartalnika „Karta”. Również tam ich doświadczenia wojenne zostały opowiedziane przede wszystkim poprzez zachowane wspomnienia siedmiorga weteranów (Galdamez, Sanigórski 2017, s. 4-45).

Materiały do poświęconego dąbrowszczakom numeru „Karty” opracowali Jeremi Galdamez (28 lat) i Maciej Sanigórski (29 lat), którzy w 2015 roku założyli inicjatywę Łapy Precz od Dąbrowszczaków, a w 2017 przekształcili ją w zarejestrowane Stowarzyszenie Ochotnicy Wolności. To oni zorganizowali w Warszawie środowisko osób sprzeciwiających się zmianie nazwy ulicy Dąbrowszczaków i od czerwca 2015 roku podjęli szereg działań mających na celu upowszechnienie wiedzy o tych patronach i zdobycie poparcia społecznego na rzecz ich uhonorowania. Rozpoczęli od udziału w posiedzeniach Komisji ds. Nazewnictwa Miejskiego, w trakcie których sprzeciwiali się planom dekomunizacyjnym podnoszonym przez radnych PiS. Przeprowadzili również akcję zmierzającą do społecznej legitymizacji ich postawy, zorganizowali między innymi internetową petycję w obronie nazwy ulicy Dąbrowszczaków, którą podpisało kilkaset osób z Polski i z zagranicy. Działali także lokalnie, wraz z innymi osobami zaangażowanymi $\mathrm{w}$ tę sprawę zbierając podpisy pod przygotowaną petycją wśród mieszkańców tej oraz sąsiednich ulic. W ten sposób w ciągu dziewięciu dni uzyskali około 1700 podpisów. Petycja została przekazana radnym Warszawy w celu przekonania ich o potrzebie bronienia głosu mieszkańców (Śmigiel, Osowski 2016). Inną petycję wysłali do wojewody mazowieckiego Zdzisława Sipiery. Podpisało ją kilkadziesiąt osób, między innymi ze świata nauki i kultury ${ }^{12}$.

Jeremi Galdamez od lat działa w szeroko rozumianym środowisku lewicowym, w tym w Związku Zawodowym Inicjatywa Pracownicza. W rozmowie wyznał, że chociaż już wcześniej interesował się historią lewicy, to temat dąbrowszczaków stał mu się bliski dopiero po pojawieniu się $\mathrm{w}$ mediach informacji o planowanym przemianowaniu ich warszawskiej ulicy. Kolejnym czynnikiem ważnym dla sposobu myślenia oraz działania $\mathrm{w}$ tej sprawie było nawiązanie kontaktu $z$ międzynarodowymi organiza-

\footnotetext{
12 Za działania upamiętniające dąbrowszczaków Galdamez i Sanigórski w styczniu 2017 roku otrzymali „Stołek” - nagrodę „Gazety Stołecznej”, „Stołki” $i$ „Nogi” przyznane. Antynagroda dla Gronkiewicz-Waltz. A nagroda czytelników?, 17 stycznia (http://warszawa.wybor cza.pl/warszawa/1,34862,21257689,stolki-i-nogi-przyznane-antynagroda-dla-gronkiewiczwaltz.html).
} 
cjami zajmującymi się upamiętnianiem Brygad Międzynarodowych. Od 2016 roku członkowie Inicjatywy, a następnie Stowarzyszenia Ochotnicy Wolności, brali udział w hiszpańskich obchodach rocznicowych upamiętniających wybuch wojny domowej. Stopniowo poszerzał się zakres podejmowanych przez nich działań. Oprócz uczestnictwa w posiedzeniach samorządu, pisania petycji i zbierania pod nimi podpisów organizują spotkania i debaty na temat wojny domowej, w tym uroczystości rocznicowe przy pomniku poświęconym dąbrowszczakom na Cmentarzu Powązkowskim. Prowadzą ponadto działalność publicystyczną, gromadzą materiały archiwalne i dążą do ich publikacji. Podjęli również działania w celu upamiętnienia dąbrowszczaków w przestrzeni publicznej Warszawy (w formie poświęconego im muralu).

Również w innych miastach w Polsce inicjatywa Łapy Precz od Dąbrowszczaków spotkała się z odzewem środowisk młodej lewicy. W Olsztynie sprzeciw wobec dekomunizacji tamtejszej ulicy Dąbrowszczaków (jednej z największych i najbardziej reprezentacyjnych ulic miasta) został zorganizowany przez kilkanaście osób, członków partii Razem. Jednym z inicjatorów tych działań był Bartosz Grucela (33 lata), dla którego obrona ulicy Dąbrowszczaków wynikała z poczucia obowiązku obrony „lewicowych bohaterów w przestrzeni publicznej Polski”. Grupa ta, podobnie jak w Warszawie, skoncentrowała się na przypomnieniu społeczności lokalnej, kim byli dąbrowszczacy, oraz dążeniu do zdobycia poparcia mieszkańców na rzecz niezmieniania nazwy ulicy. W tym celu 10 czerwca 2016 r., podczas festynu ulicznego „Święto ulicy Dąbrowszczaków” zorganizowano happening pod nazwą „Pamiętajmy o Dąbrowszczakach”. W rozstawionym namiocie $\mathrm{w}$ asyście dwóch rekonstruktorów historycznych została wyświetlona prezentacja przybliżająca historię dąbrowszczaków, rozdawano ulotki oraz zbierano podpisy pod petycją w obronie nazwy ulicy. W trakcie tej i kilku kolejnych akcji udało im się zebrać 1000 podpisów, które zostały złożone na posiedzeniu Komisji Gospodarki Komunalnej. Dzięki tym działaniom przekonano radnych oraz prezydenta Olsztyna nie tylko do pozostawienia nazwy ulicy, ale także do zaskarżenia w Najwyższym Sądzie Administracyjnym decyzji o jej zmianie wydanej przez wojewodę warmińsko-mazurskiego (przy czym o pomoc w napisaniu odwołania od tej decyzji radni zwrócili się do inicjatorów akcji). W rezultacie sąd, przychylając się do wniosku radnych, zgodził się, że nie można jednoznacznie określić dąbrowszczaków jako komunistów, a w związku z tym nie podlegają oni postanowieniom tzw. ustawy dekomunizacyjnej.

Gdańsk jest trzecim miastem w Polsce, w którym znaleźli się ludzie gotowi bronić miejscowej ulicy Dąbrowszczaków. W działania takie jak 
protesty, zbieranie podpisów oraz publiczne dyskusje z pracownikami IPN zaangażowały się przede wszystkim osoby związane ze Stowarzyszeniem Lepszy Gdańsk, z Ruchem Sprawiedliwości Społecznej oraz lokalni członkowie partii Razem. Jedną z osób najaktywniejszych w tym gronie jest Przemysław Kmieciak (35 lat), który działa w Stowarzyszeniu Lepszy Gdańsk, a jednocześnie prowadzi popularny w środowiskach młodej lewicy profil na portalu Facebook pt. „Przywróćmy Pamięć o Patronach Wyklętych”. Jego zadaniem - podobnie jak profilu „Historia Czerwona" Piotra Ciszewskiego - jest upowszechnianie wiedzy o historycznych patronach lewicy, między innymi poprzez podejmowanie merytorycznej dyskusji z informacjami publikowanymi w mediach społecznościowych przez Instytut Pamięci Narodowej. Twierdzi, że działa w reakcji na politykę historyczną realizowaną przez IPN, której celem jest - jak powiedział $\mathrm{w}$ rozmowie - „zawłaszczanie pamięci [...] systemowe usuwanie pewnej, niewłaściwej z punktu widzenia władzy symboliki, a nawet ta symbolika, która pozostaje lewicowa w przestrzeni publicznej jest odzierana z wszelkiej lewicowości”. Również według Jędrzeja Włodarczyka (33 lata), członka Stowarzyszenia Lepszy Gdańsk, od dwóch kadencji radnego dzielnicy, sprzeciw wobec dekomunizacji wiąże się przede wszystkim z postrzeganiem jej jako „narzędzia do uprawiania polityki niż do jakiejkolwiek rozsądnej refleksji historycznej”. Chociaż jest wnukiem dąbrowszczaka, podkreśla, że dla niego w tej sprawie najważniejszy jest sposób wprowadzania zmian, to znaczy odebranie lokalnym społecznościom wpływu na kształtowanie symboliki miejscowej przestrzeni publicznej.

Kmieciakowi, Włodarczykowi oraz innym osobom sprzeciwiającymi się dekomunizacji przestrzeni publicznej udało się nawiązać kontakt $z$ samorządem w Gdańsku. Podczas zorganizowanej przez nich konferencji prasowej przedstawili petycję na rzecz pozostawienia nazwy ulicy Dąbrowszczaków. Pod petycją podpisało się około pięciuset mieszkańców (Nietopiel 2017). Argumenty w niej wysunięte zostały również wykorzystane przez prezydenta Gdańska Pawła Adamowicza w piśmie zaskarżającym decyzję wojewody o zmianie nazwy ulicy Dąbrowszczaków.

W popularyzacji wiedzy na temat dąbrowszczaków znaczącą rolę odegrał Dariusz Zalega (44 lat) z Chorzowa. Niezależnie od pracy w związku zawodowym „Sierpień 80" w środowisku lewicy znany jest z prowadzenia na portalu Facebook strony „Zbuntowany Śląsk”. Publikuje tam materiały historyczne poświęcone głównie przedwojennej, wieloetnicznej historii robotniczego Śląska. Jak sam twierdzi, są nimi zainteresowani zarówno zwolennicy lewicy, jak i śląscy konserwatyści. W 2016 roku wyprodukował amatorski film historyczny pt. Zbuntowany Ślask. Gawęda z dziejów 
walk społecznych na Górnym Śląsku. Później wyreżyserował i wyprodukował, wspomniany już, drugi film pt. Pięść i dynamit, poświęcony zamieszkującym przedwojenny podzielony Śląsk Polakom, Niemcom, Czechom i Słowakom, którzy zdecydowali się wziąć udział w wojnie domowej w Hiszpanii. Film ten, nagrany wyłącznie przy wykorzystaniu własnych zasobów finansowych oraz dystrybuowany na płytach DVD, podczas specjalnych jego pokazów gromadził liczną publiczność niezależnie od tego, czy był wyświetlany w Berlinie, w Katowicach, czy też w Warszawie. Wykorzystując zebrane relacje historyczne, Zalega starał się osiągnąć dwa cele: upowszechnić złożoną, wielonarodową historię swego regionu oraz przedstawić fragment atrakcyjnej historii lewicy. Uwypuklił w filmie zarówno międzynarodową współpracę walczących w Hiszpanii, jak i motywacje stojące za decyzją o udziale w konflikcie oraz wyzwania, z jakimi spotkali się ci, którzy odważyli się ruszyć w tak daleką drogę.

\section{PODSUMOWANIE}

Zebrane dane pozwalają podjąć próbę udzielenia odpowiedzi na postawione na początku pytania badawcze.

Pierwsze pytanie dotyczyło czynników, które wpłynęły na to, że pamięć o dąbrowszczakach ponownie stała się punktem sporu we współczesnej Polsce. Bez wątpienia bezpośrednim czynnikiem, który przyczynił się do ponownego pojawienia się tego tematu w dyskursie publicznym, było włączenie hiszpańskich weteranów do kategorii symboli podlegających zamierzonej przez władze dekomunizacji przestrzeni publicznej. Świadczą o tym zarówno zebrane informacje, jak i jednoznaczne deklaracje respondentów. Ustawa dekomunizacyjna została odebrana jako próba usunięcia patronów lewicy ze świadomości społecznej, a przez to sposób na zdobycie przez obóz prawicy pełnej hegemonii w przestrzeni pamięci Polaków. Taki sposób interpretacji, dominujący wśród respondentów, wiązał się z postrzeganiem dekomunizacji w szerszym kontekście działań podejmowanych przez IPN - w zestawieniu $z$ wprowadzaniem do oficjalnej polityki historycznej elementów nacjonalistycznych, takich jak uhonorowanie działań Narodowych Sił Zbrojnych czy upamiętnianie tzw. żołnierzy wyklętych, czyli uczestników powojennego podziemia niepodległościowego i antykomunistycznego.

W sposób pośredni ponowne pojawienie się tematu dąbrowszczaków ma związek z przemianami pokoleniowymi, w wyniku których coraz aktywniejszą i istotniejszą rolę $\mathrm{w}$ przestrzeni publicznej zaczyna pełnić pokolenie osób urodzonych w latach osiemdziesiątych i dziewięćdziesiątych- 
tych, które — jak można przypuszczać — pod względem tzw. doświadczeń formacyjnych w znaczący sposób różni się od pokolenia wcześniejszego. Najważniejsza różnica $w$ obszarze pamięci społecznej wiąże się z brakiem osobistych doświadczeń związanych z życiem w chylącej się ku upadkowi PRL, możliwością obserwacji wielu negatywnych zjawisk związanych z warunkami życia i pracy w systemie neoliberalnego kapitalizmu. Wśród przedstawicieli tego pokolenia postawy antykomunistyczne są dosyć powszechne, jednak symbole komunizmu i antykomunizmu są rozumiane w inny sposób niż we wcześniejszych pokoleniach. Dla młodych ludzi o przekonaniach lewicowych dąbrowszczacy mogą ponownie stać się inspirującymi bohaterami, z jednej strony ze względu na atrakcyjność mitu Brygad Międzynarodowych, z drugiej zaś - ze względu na brak doświadczeń z propagandowym wykorzystaniem ich legendy w czasach PRL.

Z tym wiąże się odpowiedź na kolejne pytanie - jak obecnie ocenia się rolę historyczną dąbrowszczaków i jakie nadaje się im znaczenia? Analiza zebranych materiałów pozwala stwierdzić, że ukształtowane już w latach trzydziestych opinie i stanowiska na temat przyczyn wojny domowej w Hiszpanii oraz udziału w niej polskich ochotników do tej pory nie uległy większym zmianom. Wojciech Opioła (2016, s. 254) dowodzi, że po roku 1989 środowiska społeczno-polityczne w Polsce powróciły do narracji występujących w publicystyce sprzed 1939 roku. Środowiska prawicowe popierają generała Franco jako obrońcę Hiszpanii i Kościoła katolickiego przed komunizmem, publicyści liberalno-lewicowi starają przedstawić ten konflikt jako obronę Republiki przed puczem generałów, a przedstawiciele młodej lewicy uwypuklają przede wszystkim cel walki z faszyzmem.

Jednocześnie co najmniej od kilku lat środowiska polskiej lewicy dostrzegają swą słabość $\mathrm{w}$ trudności $\mathrm{z}$ odnalezieniem i upowszechnieniem atrakcyjnych bohaterów polskiego ruchu lewicowego (Kwiatkowski 2017, s. 67-74). Uważają, że brak takich postaci w przestrzeni popkultury oraz dziedzictwo propagandy PRL znacznie utrudniają, choć nie uniemożliwiają, podejmowanie takich działań. Podjęli więc zadanie upowszechnienia historii dąbrowszczaków, gdyż dostrzegli jej znaczny potencjał mitotwórczy.

Postrzegana atrakcyjność tych bohaterów opiera się na kilku elementach, co znajduje wyraz w stosowanych wobec nich określeniach. Bardzo mocno akcentowany jest element woluntaryzmu działań dąbrowszczaków. Hasło „Ochotnicy Wolności” odwołuje się do podstawowych wartości liberalnych. Zawarte jest $\mathrm{w}$ nim podkreślenie indywidualnego wyboru oraz motywacja działania jako niezgody na odbieranie wolności. Nie brakuje w tym haśle również nawiązania do atrakcyjnej kontrkulturowej awantur- 
niczości. Duże znaczenie ma odwoływanie się w dyskursie historycznym do walki z faszyzmem w Hiszpanii, która poprzedzała mającą już wkrótce nastąpić walkę $z$ faszyzmem w Polsce. Znajduje to wyraz w przywoływanym także obecnie haśle: "Jeśli dziś padnie Madryt, jutro padnie też Warszawa".

W hiszpańskiej legendzie nie brakuje odniesień do klasycznego kanonu narodowego. Zakorzenienie mitu dąbrowszczaków w polskim kanonie romantycznym budowane było już podczas powstawania tych oddziałów, między innymi poprzez przyjęcie jako patronów polskich dziewiętnastowiecznych bohaterów narodowych, w tym wieszcza Adama Mickiewicza, uczestników walk z caratem Jarosława Dąbrowskiego i Bartosza Głowackiego oraz socjalisty Ludwika Waryńskiego (Różycki 2013, s. 170). Obrońcy dąbrowszczaków, podobnie jak sami dąbrowszczacy, posługują się hasłem dziewiętnastowiecznych powstańców „Za Wolność Naszą i Waszą”. W nawiązaniu do mitu żołnierzy wyklętych, propagowanego przez prawicę, uczestnicy hiszpańskiej wojny są obecnie określani jako „Wyklęci spośród wyklętych” oraz „Patroni wyklęci”, co ma zwrócić uwagę na niesprawiedliwe i propagandowe przepisywanie ich historii.

Ostatnie pytanie dotyczyło tego, kim są współcześni aktorzy społeczni stojący za obroną i promocją legendy dąbrowszczaków w Polsce? Zebrane w trakcie wywiadów informacje pozwalają na szacunkową ocenę liczby tych osób i pewną generalizację co do strukturalnych charakterystyk tego środowiska. Protesty w obronie ulic Dąbrowszczaków odbyły się w trzech miastach w Polsce: Warszawie, Olsztynie i Gdańsku. W każdym z tych protestów brało udział od kilkunastu do około trzydziestu osób. Z czasem współpraca między nimi się zacieśniała - w wydarzeniu organizowanym $\mathrm{w}$ jednym $\mathrm{z}$ tych miast brały udział osoby pochodzące $z$ innych. Można więc szacować, że $\mathrm{w}$ ciągu ostatnich trzech lat $\mathrm{w}$ zbieraniu podpisów pod petycjami, $\mathrm{w}$ publikowaniu informacji na ich temat oraz $\mathrm{w}$ organizacji wydarzeń upamiętniających dąbrowszczaków czynnie uczestniczyło około kilkudziesięciu osób. Osoby te pochodzą z różnych środowisk, ale można przypuścić, że na potencjał mobilizacyjny ich protestów pozytywnie wpłynęło zaangażowanie organizacji społeczno-politycznych, takich jak partia Razem, Ruch Sprawiedliwości Społecznej oraz Stowarzyszenie Lepszy Gdańsk. Pod względem ilościowym w skali całego społeczeństwa jest to zatem środowisko niszowe. Jednak na przykład duże zainteresowanie filmem Pięść $i$ dynamit wskazuje na możliwość istnienia znacznie szerszej grupy Polaków wspierających projekt przywrócenia patronów lewicy oraz antyfaszyzmu do centrum polskiej pamięci społecznej. Trzeba przy tym pamiętać, że w przestrzeni pamięci społecznej to nieliczni, ale zdetermi- 
nowani aktorzy pamięci często są w stanie wprowadzić zmianę, zwłaszcza w obliczu ambiwalencji i poczucia własnej niekompetencji większości społeczeństwa.

W grupie respondentów - podobnie jak wśród wszystkich uczestników protestów - zdecydowaną większość stanowiły osoby w wieku około trzydziestu lat. Są to więc reprezentanci pokolenia, którego młodość i dojrzewania przypadły już na czasy III RP.

Trójka spośród jedenastu to wnukowie dąbrowszczaków. Można jednak wnioskować, że przekaz na ich temat nie zawsze zajmował istotne miejsce $\mathrm{w}$ historiach rodzinnych. Wśród pozostałych większość mogła wskazać na przekazanie ogólnych wartości lewicowych w sposób pośredni lub bezpośredni przez członków ich rodzin. Wszyscy deklarowali znaczące zainteresowanie historią, przy jednoczesnej niezgodzie na sposób uprawiania historii przez IPN. Poza członkostwem kilku $z$ nich w powstałej w 2015 roku partii Razem nikt nie uczestniczył wcześniej w krajowej polityce partyjnej. Kilka osób miało jednak doświadczenie w działalności niezależnych organizacji społecznych oraz w niesformalizowanych strukturach środowisk lewicowych. Przypuszczalnie to właśnie doświadczenie w „ulicznej” działalności społecznej przełożyło się na ich skuteczność w organizacji protestów oraz zbiórek podpisów pod petycjami. Jednocześnie dobre wykształcenie oraz umocowanie $\mathrm{w}$ instytucjach państwowych pozwoliło im podjąć skuteczny dialog z ciałami samorządowymi ${ }^{13}$.

Charakterystyczna wydaje się ogromna aktywność i różnorodność działań podejmowanych w celu przypomnienia historii dąbrowszczaków. Oprócz zbiórek podpisów i organizacji protestów w ciągu trzech lat napisano wiele tekstów prasowych, przeprowadzone zostały artystyczne performanse, powstały opracowania popularno-historyczne, film o dąbrowszczakach, przygotowano również projekt muralu na jednej z kamienic w Warszawie. Respondenci często deklarowali prowadzenie indywidualnych badań w archiwach państwowych między innymi w celu zdobycia argumentów do dyskusji z pracownikami IPN. Warta podkreślenia jest niezwykle aktywna działalność internetowa na prowadzonych przez poszczególne osoby stronach $\mathrm{w}$ mediach społecznościowych. To między innymi za ich pomocą zostały nawiązane kontakty $z$ zagranicznymi środowiska-

13 Wśród respondentów jedna osoba studiuje, osiem ma wyższe wykształcenie magisterskie, jedna przygotowuje pracę doktorską, a jedna uzyskała tytuł naukowy doktora. W większości są oni absolwentami kierunków humanistycznych i społecznych. Zazwyczaj są to studia politologiczne, socjologiczne, historyczne, prawnicze lub w zakresie stosunków międzynarodowych. Kilka osób pracuje w instytucjach kultury, nauki oraz w placówkach samorządowych. 
mi lewicowymi upamiętniającymi członków Brygad Międzynarodowych. Ta proliferacja różnego rodzaju interwencji w przestrzeń pamięci społecznej zdecydowanie kontrastuje $z$ raczej pasywną postawą obrońców pamięci o dąbrowszczakach przed 2015 rokiem. Ci nowi i zazwyczaj młodzi aktorzy pamięci zagospodarowują pustkę $\mathrm{w}$ debacie historycznej po lewej stronie sceny politycznej — pustkę, której nie zdołali wypełnić ani kombatanci lewicowej części opozycji solidarnościowej, ani postkomunistyczni obrońcy dziedzictwa PRL, ani rozproszone środowiska liberalno-lewicowe, które nie chciały się angażować w debaty historyczne i programowo „wybierały przyszłość".

„Uprzątanie” przestrzeni publicznej z symboliki poprzedniego syste$\mathrm{mu}$, przy jednoczesnym wprowadzaniu nowych elementów związanych $z$ kanonem pamięci środowisk prawicowych, może być interpretowane jako forma obejmowania dominacji w przestrzeni symbolicznej kraju. Po zdobyciu władzy przez Prawo i Sprawiedliwość oprócz struktur partyjnych oraz licznych lokalnych środowisk prawicowych w działania te zostały zaangażowane również centralne instytucje państwowe, w tym Instytut Pamięci Narodowej. Oficjalnym uzasadnieniem wprowadzanych zmian było dążenie do upowszechnienia $\mathrm{w}$ polskim społeczeństwie, a zwłaszcza wśród młodych Polaków, pożądanej postawy patriotycznej. Podstawowe wektory prawicowej polityki historycznej, to znaczy antykomunizm, oparcie się na autorytecie Kościoła katolickiego oraz promocja postaw militarystycznych i nacjonalistycznych należą do tradycji polskiego obozu narodowego jeszcze z okresu przedwojennego. Odwołując się do teorii polityki pamięci, można uznać, że ostatecznym celem tych działań jest zdobycie przez władze hegemonii w przestrzeni pamięci społecznej, co z kolei powinno wpłynąć na przekształcenie $\mathrm{w}$ pożądanym kierunku tożsamości społecznej Polaków oraz zbudowanie w ten sposób trwałego poparcia dla rządzącego obozu politycznego. Wśród trudności związanych z osiągnięciem tego celu wymienia się zazwyczaj złożony charakter pamięci społecznej, udział w tej rywalizacji wielu aktorów pamięci oraz stopniowo następujące przemiany generacyjne, które niosą potencjalne wyzwanie dla stabilności każdego systemu pamięci. Historia obrony pamięci o dąbrowszczakach wskazuje na sprawczość każdego z tych czynników. Wydaje się jednak, że przemiany generacyjne mają znaczenie najistotniejsze. Wyzwanie rzucone oficjalnej polityce pamięci przez nieliczne grupy lewicowych społeczników uwidacznia, jak w sprzyjających okolicznościach pozornie słaby, ale wyposażony w silną narrację i determinację aktor pamięci jest w stanie podważyć działania znacznie silniejszych $\mathrm{w}$ tym polu przeciwników. 


\section{BIBLIOGRAFIA}

Aguilar Paloma, 2002, Memory and Amnesia: The Role of the Spanish Civil War in the Transition to Democracy, Berghahn Books, New York-Oxford.

Aguilar Paloma, Ramirez-Barat Clara, 2016, Generational Dynamics in Spain: Memory Transmission of a Turbulent Past, „Memory Studies”, t. 12(2), s. 213-229.

Aronoff Myron J., Kubik Jan, 2013, Anthropology and Political Science: A Convergent Approach, Berghahn Books.

Assmann Aleida, 2012, To Remember or to Forget: Which Way Out of a Shared History of Violence?, w: Aleida Asmann, Linda Shortt (red.), Memory and Political Change, Palgrave Macmillan, New York, s. 53-70.

Biernacka Maja, 2017, Wojna na pomniki w Katalonii, czyli co zrobić z upamiętnieniem bitwy pod Ebro, „Przegląd Humanistyczny” nr 2, s. 11-21.

Bukalska Patrycja, 2007, Fotografia z królem Carlosem, „Tygodnik Powszechny”, 23 kwietnia.

Chodakiewicz Marek Jan, 1997, Zagrabiona pamięć. Wojna w Hiszpanii 1936-1939, Fronda, Warszawa.

Chwedoruk Rafał, 2018, Polityka historyczna, Wydawnictwo Naukowe PWN, Warszawa.

Ciszewski Piotr, 2018, Dąbrowszczacy. Na świecie szanowani, w Polsce poniżani, Fundacja Oratio Recta, Warszawa.

Connerton Paul, 2008, Seven Types of Forgetting, „Memory Studies”, nr 1 (1), s. 59-71.

Corning Amy D., 2010, Emigration, Generation, and Collective Memories, „Social Psychology Quarterly", t. 73(3), s. 223-244.

Dirks Nicholas B., Eley Geoff, Ortner Sherry B., 1994, Introduction, w: Nicholas B. Dirks, Geoff Eley, Sherry B. Ortner, Culture/Power/History: A Reader in Contemporary Social Theory, Princeton University Press, Princeton, s. 3-45.

Fogu Claudio, Kansteiner Wulf, 2006, The Politics of Memory and the Poetics of History, w: Richard Ned Lebow, Claudio Fogu, Wulf Kansteiner (red.), The Politics of Memory in Post-War Europe, Duke University Press, Durham, s. 284-310.

Galdamez Jeremi, Sanigórski Maciej, 2017, Ochotnicy wolności, „Karta”, nr 90, s. 4-45.

Gellner Ernest, 1987, Culture, Identity and Politics, Cambridge University Press, Cambridge-New York.

Giertych Maciej, 2006, Przemówienie Macieja Giertycha 4 lipca 2006 podczas debaty w Parlamencie Europejskim w 70. rocznice zamachu stanu generała Franco, „Gazeta Wyborcza”, 5 lipca.

Gontarczyk Piotr, 2007, Dąbrowszczacy — żotnierze Stalina, „Rzeczpospolita”, 7 maja.

Gryta Janek, 2019, Generational Succesion, Culture, and Politics: The Shaping of Euro-Atlantic Sites of Memory, „Memory Studies” (DOI: 10.1177/1750698018823232).

Katzenstein Peter J., 1996, The Culture of National Security: Norms and Identity in World Politics, Columbia University Press, New York.

Keller Patricia, 2012, The Valley, the Monument, and the Tomb: Notes on the Place of Historical Memory, „Hispanic Issues On Line”, nr 11.

Kubik Jan, 1994, The Power of Symbols against the Symbols of Power: The Rise of Solidarity and the Fall of State Socialism in Poland, Penn State University Press, University Park, PA.

Kwiatkowski Piotr T., 2008, Pamięć zbiorowa społeczeństwa polskiego w okresie transformacji, Scholar, Warszawa. 
Kwiatkowski Piotr T., 2009, Społeczne tworzenie zbiorowej niepamięci, w: Lech M. Nijakowski (red.), Etniczność, pamięć, asymiliacja: wokót problemów zachowania tożsamości mniejszości narodowych $i$ etnicznych $w$ Polsce, Wydawnictwo Sejmowe, Warszawa.

Kwiatkowski Piotr T., 2017, Pamięć rewolucji 1905 roku po upadku PRL: Wykluczanie z narodowej tradycji i próby nowej interpretacji, „Przegląd Humanistyczny”, t. 61(2), s. 61-75.

Laitin David, 1986, Hegemony and Culture: Politics and Religious Change among the Yoruba, The University of Chicago Press, Chicago.

Lipiński Artur, 2014, Pamięć zbiorowa w naukach politycznych — topografia pola badań, „Kultura i Społeczeństwo", nr 3, s. 29-60.

Mannheim Karl, 1952, Essays in the Sociology of Knowledge, Routledge, London.

March James G., Olsen Johan P., 2005, Instytucje. Organizacyjne podstawy polityki, tłum. Dariusz Sielski, Scholar, Warszawa.

MAS, 2007, Madryt broni Dąbrowszczaków przed polskim rzadem, „Gazeta Wyborcza”, 25 marca.

Misztal Barbara A., 2003, Theories of Social Remembering, Open University Press.

Nietopiel Aleksandra, 2017, „NIE” dla dekomunizacji ulicy Dąbrowszczaków w Gdańsku. Już pót tysiaca podpisów pod petycja (https://radiogdansk.pl/wiadomosci/item/61383-nie-dla-de komunizacji-ulicy-dabrowszczakow-w-gdansku-juz-pol-tysiaca-podpisow-pod-petycja).

Ochman Ewa, 2010, Soviet War Memorials and the Re-construction of National and Local Identities in Post-communist Poland, „Nationalities Papers”, nr 38(4), s. 509-530

Ochman Ewa, 2017, When and Why is the Forgotten Past Recovered? The Battle of Warsaw, 1920 and the Role of Local Actors in the Production of Memory, „Memory Studies” (DOI: 10.1177/ 1750698017709874).

Olick Jeffrey K., 1999, Collective Memory: The Two Cultures, „Sociological Theory”, t. 17(3), s. 333-348.

Opioła Wojciech, 2014, O szkodliwości generalizowania w historii. Przypadek dąbrowszczaków, w: Kamil Minkner, Lech Rubisz (red.), Antynomie polityczności. Artykuty, eseje i szkice dedykowane Profesor Barbarze Goli, Wydawnictwo Uniwersytetu Opolskiego, Opole.

Opioła Wojciech, 2016, Hiszpańska wojna domowa w polskich dyskursach politycznych. Analiza publicystyki 1936-2015, Wydawnictwo Uniwersytetu Opolskiego, Opole.

Osowski Jarosław, 2016, Dekomunizacja ulic. PiS chce zmienić nawet 30 nazw: Armii Ludowej, ZWM, „Gazeta Wyborcza”, 3 września.

Osowski Jarosław, 2016, „Odrobine patriotyzmu, do cholery”, czyli dekomunizatorka Olga Johann $z$ PiS, „Gazeta Wyborcza”, 25 listopada.

Różycki Bartłomiej, 2013, Dąbrowszczacy i pamięć o hiszpańskiej wojnie domowej w Polsce Ludowej, „Pamięć i Sprawiedliwość, nr 1, s. 167-212.

Schuman Howard, Belli Robert F., Bischoping Katherine, 1997, The Generational Basis of Historical Knowledge, w: James W. Pennebaker, Dario Paez, Bernard Rime (red.), Collective Memory of Political Events: Social Psychological Perspectives, Lawrence Erlbaum Associates, Mahwah, N.J., s. 47-78.

Schuman Howard, Rodgers Willard L., 2004, Cohorts, Chronology, and Collective Memories, „Public Opinion Quarterly", t. 68(2), s. 217-254.

Schuman Howard, Corning Amy D., 2011, Generational Memory and the Critical Period: Evidence for National and World Events, „Public Opinion Quarterly”, t. 76(1), s. 1-31.

Skibiński Paweł, 2004, Państwo generała Franco. Ustrój Hiszpanii w latach 1936-1967, Arcana, Kraków. 
Stasiński Maciej, 2010, Socjaliści Zapatero myśla lekko, polscy nie powinni, „Gazeta Wyborcza”, 5 lipca.

Swidler Ann, 1986, Culture in Action: Symbols and Strategies, „American Sociological Review”, t. 51(2), s. 273-286.

Szacka Barbara, 2006, Czas przeszty — pamięć — mit, Scholar, Warszawa.

Śmigiel Martyna, Osowski Jarosław, 2016, Dekomunizacja ulic. Radni otrzymali petycję w sprawie ul. Dąbrowszczaków (http://warszawa.wyborcza.pl/warszawa/1,34862,20987391,dekom unizacja-ulic-radni-otrzymali-petycje-w-sprawie-ul-dabrowszczakow.html).

Toruńczyk Barbara, 2007, Apel Antygony. List otwarty w sprawie Dąbrowszczaków, „Gazeta Wyborcza", 25 kwietnia.

Tryc-Ostrowska Małgorzata, 2010, Chca wyrzucić Franco z grobu i wysadzić krzyż, „Rzeczpospolita”, 18 listopada.

Wangler Alexandra, 2012, Rethinking History, Reframing Identity: Memory, Generations, and the Dynamics of National Identity in Poland, Springer, Wiesbaden.

Weber Max, 1998, Polityka jako zawód i powołanie, tłum. Andrzej Kopacki, Paweł Dybel, Znak-Fundacja im. Stefana Batorego, Kraków-Warszawa.

Wieczorkiewicz Patrycja, 2017, Dąbrowszczacy maja w centrum tablice pamiatkowa, wyborcza.pl, 8 października (http://warszawa.wyborcza.pl/warszawa/7,54420,22484932,dabrowsz czacy-maja-w-centrum-tablice-pamiatkowa.html).

Zenderowski Radosław, 2011, Pamięć i tożsamość narodowa, „Athenaeum”, nr 28, s. 149-166. Ziemkiewicz Rafał, 2007, Dąbrowszczacy - żotnierze niestusznej sprawy, „Rzeczpospolita”, 27 kwietnia.

\title{
DEFENDING THE POLISH VOLUNTEERS IN THE SPANISH CIVIL WAR: BETWEEN THE SYMBOL OF ANTI-FASCISM AND THE POLICY OF ANTI-COMMUNISM
}

\author{
Jakub Wysmułek \\ (Institute of Political Studies PAS)
}

\begin{abstract}
This article concerns the changes that have been occurring in Poles' collective memory not only in regard to historical policy but also in regard to spontaneous social activeness. The author's empirical basis was formed by interviews with the organizers and participants of protests against plans to change the name of a street [ul. Dąbrowszaków], and of other activities in the years 2016-2019 aimed at popularizing the history of. The problem is presented in the context of the debate among historians, publicists, and politicians of right-wing and left-liberal circles over the historical policy. The author interprets attempts to remove the civil war volunteers from the public sphere in Poland as part of a broader historical policy aimed at achieving cultural hegemony over Poles' social memory and identity. He analyzes the protests in defense of this volunteers primarily in the context of the generational changes that have enabled the appearance of a new, leftist "memory actor."
\end{abstract}


Key words / słowa kluczowe

Polish veterans of the Spanish Civil War (1936-1939), dąbrowszczacy / polscy weterani wojny domowej w Hiszpanii (1936-1939), historical policy in Poland / polityka historyczna w Polsce, social memory / pamięć społeczna, generational changes / zmiany pokoleniowe 